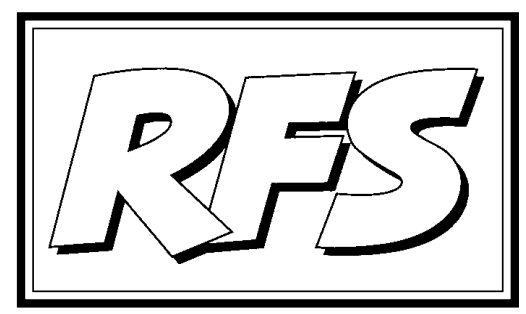

Revista de Fomento Social, 56 (2001), 589-626

\title{
Paradojas de la migración. Aspectos antropológicos
}

Paloma FERNÁNDEZ DE LA HOZ ${ }^{1}$

\section{Realidades al margen}

Abdelmalek Sayad (1933-1998), emigrante argelino y sociólogo francés, solía referirse con frecuencia a las "paradojas de la migración"2, empleando el término en su sentido originario: "para-doxa", lo que existe o tiene lugar junto a la opinión; algo así como un cuerpo que pasara junto a otro sin llegar a encontrarse o toparse con él. Ciertamente, en muchos aspectos referidos a los inmigrantes y las poblaciones de los países receptores, una es la

1 Miembro de la Academia Social Católica de Austria; trabaja en investigación sobre vida familiar, migración y exclusión social. Este artículo ha surgido a partir del texto de una conferencia pronunciada en el seminario internacional de jesuitas europeos celebrado el 28 de agosto de 2001 (EUROJ ESS) en Berlín y dedicado a las migraciones en la UE. Por ello se ha respetado su carácter originario de ensayo o lectura personal. Véase una crónica de dicho encuentro en este mismo número.

2 SAYAD (1991), p. 17. 
realidad vivida, y otra la realidad social imaginada o percibida. La presente reflexión se centra en esos aspectos paradójicos debido a su importancia en orden a la integración ${ }^{3}$ social de España y de los países miembros de la Unión Europea.

Plantearse los aspectos antropológicos de la migración ${ }^{4}$ implica ahondar ante todo en los elementos culturales de los procesos migratorios, es decir, en la manera de sentir, de pensar y de actuar de las personas y grupos implicados, sin olvidar por ello las coordenadas estructurales en que dichas percepciones y estrategias humanas se enmarcan, alimentando a su vez una dinámica que las perpetúa o las modifica. Resulta a todas luces imposible captar en una visión sintética toda esa complejidad, entre otras razones ya que son muchos los tipos de flujos migratorios y más aún los factores humanos que determinan la construcción social de los mismos. Sin embargo, es posible resaltar algunos puntos decisivos en orden a una orientación de las políticas migratorias. Cara un futuro inmediato de los países de Unión Europea no es indiferente el marco de convivencia que hoy se está configurando en cada uno de ellos. Y en cuanto a dicho marco, no da igual cómo actúen, sientan y se figuren la migración tanto las poblaciones de los países de acogida como quienes emigran. Por todo ello, la búsqueda de elementos antropológicos significativos para orientar conscientemente la convivencia cotidiana y la praxis política, ha de tener lugar a partir de dos perspectivas, la de los inmigrantes y sus descendientes, por un lado, y la de la población de los países receptores, por otro.

\section{Emigrantes - Inmigrantes}

\subsection{La doble ausencia}

El término "inmigrante" abarca una categoría muy heterogénea de personas sobre cuyos intereses, actitudes y comportamientos apenas es posible hacer comentarios generales. En este grupo se cuentan las personas que han abandonado su país en busca de trabajo o por razones de inseguridad

3 En este artículo se emplea la palabra integración como vocablo normativo político, concretamente, como un proceso a través del cual los miembros de un país van alcanzado cada vez mayores grados de participación social. En la tradición de los estados sociales europeos, dicha participación suele reflejarse en el disfrute de derechos civiles, sociales y políticos. Cfr.: Comunidad Europea (2001b), s.p.

4 Aquí se considera únicamente los fenómenos de migración internacional a largo plazo. 
sociopolítica, así como los familiares que se les suman. Lo único que este grupo social tiene en común es la experiencia de haber dejado su país de origen para ir a vivir a otro lugar. La característica de la migración consiste, por tanto, en el abandono de un entorno conocido para llegar a un país en el que muchas cosas son nuevas. Tanto los inmigrantes transfronterizos 0 temporeros, como los que se establecen a largo plazo en el país receptor han de adaptarse a un nuevo entorno social en el que la lengua a menudo es nueva y la vida social está articulada de otra manera. Con el tiempo, los que un día fueron recién llegados, van organizando su vida, se insertan de diferentes maneras en el país receptor, suelen traer a su familia o fundar una nueva. Pero quien emigra vive entre dos polos de referencia vital, por eso la problemática explícita e implícita es siempre la de la inserción en la sociedad receptora de estas personas "atopos", "doblemente ausentes", viviendo en una sociedad que "no se plantea el problema de los inmigrantes sino en la medida en que los inmigrantes le plantean problemas"5.

A partir de esta primera aproximación puede apreciarse ya cuán deficitario resulta el término que define a estas personas. Inmigrar es siempre haber emigrado. La vida no ha comenzado con la llegada al país receptor, sino antes, en el país de origen. Y ese pasado está vivo como referencia afectiva, familiar, social y cultural. Ello no equivale a afirmar que todos los inmigrantes sean -y sobre todo, permanezcan- diferentes culturalmente a la población de origen. Tal afirmación supondría establecer dos bloques monolíticos que, como tales, sólo pueden existir en la imaginación: el de la población del país receptor, que se presume culturalmente homogéneo, y el de los recién llegados, necesariamente diferentes. La realidad es mucho más compleja: el pluralismo cultural de los países de la UE no es un producto importado, sino resultado de la evolución interna de la cultura occidental y de las formas políticas cada vez más abiertas en que ésta ha ido encauzando la convivencia social. Por otra parte, la variedad de perfiles biográficos y culturales entre los inmigrantes es incontable. Evidentemente, a medida que los canales migratorios se van haciendo más internacionales y globales, y los inmigrantes van llegando de países más lejanos al receptor, crece la posibilidad de que existan contrastes culturales en el interior de un mismo país. Pero ello no sustenta la imagen de dos bloques culturales compactos, sino todo lo contrario, la debilita.

5 Bourdieu (1999), pp. 11-12. 
Exponer una antropología de la migración desde la perspectiva de los inmigrantes entraña dos dificultades. La primera es la enorme pluralidad de trayectorias personales. La segunda es el hecho de que muchos de los aspectos más significativos escapan a un análisis estructural. De ahí la necesidad de practicar una "sociología de lo pequeño" sin por ello empequeñecer la sociología ${ }^{6}$-con casuística, o con aplicaciones de observaciones fuera del contexto en que han sido realizadas. En la vida cotidiana narrada por los propios inmigrantes o por gente que vive muy cerca de ellos, resulta posible captar ciertos aspectos decisivos de su experiencia.

Por eso a continuación se expondrá un caso concreto para, a partir de éste, ofrecer algunas reflexiones acerca de la migración. Dicho caso está tomado de los trabajos de investigación sobre familias inmigrantes procedentes de la antigua Yugoslavia y de Turquía, realizados entre 1996 y 2000 en Austria? Se trata no de la biografía de un individuo, sino del proceso migratorio de una familia. Este enfoque se muestra particularmente importante debido a la importancia de los lazos familiares. Como primera instancia de socialización, la familia resulta decisiva en la transmisión de valores y pautas de conducta, su valor de orientación es grande, sobre to do allí donde los recursos sociales se reducen, lo cual suele suceder al abandonar el propio país. En el contexto migratorio los lazos familiares parecen ganar importancia. Con mucha frecuencia los parientes ayudan a superar dificultades en el país receptor, de manera que se da una fuerte relación entre diferentes formas de inserción y vida familiar ${ }^{8}$. Esta observación no equivale a asumir una imagen idílica e idealizada de la vida familiar en el contexto de la migración, en el cual, debido a la dureza de las condiciones de vida en el país receptor, a veces se producen conflictos familiares, o se agudizan problemas ya existentes, debido a que los diferentes miembros se ven afectados por el nuevo entorno social o reaccionan a éste de manera diferente. Con todo, la perspectiva familiar permite captar mejor la dinámica relacional. Por otra parte no hay que olvidar que en los países de la UE la reunificación familiar es la forma de migración más importante en nuestros días y parece que va a serlo en un futuro próximo.

6 SAYAd (1991), p. 21.

7 Fernández de la Hoz \& Pflegerl (1999a). Ibid (1999). Pflegerl \& Fernández de la Hoz (2001).

8 Dietzel-Papakyriakou (1993b), pp. 30. y ss.; 50-55. Khosrokhavar (1997), p. 26; Pumares (1996), p. 31. Tribalat et al. (1996), pp. 15, 21, 263-266; Zanfrini (1998), p. 66. 


\subsection{La familia Miric}

\subsubsection{La decisión de emigrar}

La familia Miric ${ }^{9}$ es oriunda de un pequeño valle serbio cerca de la frontera con Rumania. Se trata de un territorio claramente rural con tres pequeños pueblos cuyos habitantes se conocen y muchos de ellos están emparentados entre sí. La familia inmigrada con residencia en Viena está compuesta por un matrimonio (Marko y Svetlana, edad actual entre 50 y 55 años), dos hijos, una chica de 22 años (Janica) y un chico de 21 (Goran), la mujer de éste con 17 años (Slava) y una niña de este segundo matrimonio (casi 2 años de edad): en el pueblo quedaron los padres de Marko y la madre de Svetlana (fallecidos entre mediados de los 80 y fines de los 90). El padre de ésta trabajó unos pocos años en Viena y volvió a su localidad a fines de los años 80.

Ambos cónyuges son hijos únicos y heredaron de su respectiva familia una casa rural con animales y algunas tierras. El padre de Marko emigró a Austria a finales de los 60 permaneciendo solo en ese país durante trece años, con excepción de los periodos de vacación. De este modo, lo que se planeó como una estancia provisional con el fin de ahorrar el mayor dinero posible e invertirlo en la propia casa, se dilató hasta su jubilación.

La familia Miric vivía de la agricultura y del empleo de Marko. Este era mecánico electricista especializado en cierto tipo de motores y trabajaba en una empresa a unos kilómetros del pueblo. Svetlana se ocupaba de la casa y de la pequeña explotación agropecuaria familiar. En los años que siguieron a la muerte del presidente Tito, esta región serbia fue sintiendo los efectos de una recesión económica cada vez más aguda, hasta que llegó un punto en el que la explotación agraria resultó incapaz de alimentar a la familia y por tanto insostenible, por eso el matrimonio Miric se planteó nuevas perspectivas laborales. De este modo, en 1986, Marko, de común acuerdo con su mujer, se decidió por emigrar a Austria, si bien contra la voluntad de su padre:

(Marko). “Mi padre volvió a casa el [año] 80, y ya el [año] 81 recibió su pensión: 3.500 chelínes [unos 254 euros]. Y yo me fui el 85 . Ya no era posible trabajar allí. Él recibía una pensión de 3.500 chelínes y yo un sueldo de 500 [36,34 euros]. Yo he dicho: '¡No! Así ya no. Trabajo aquí toda la vida y recibo menos que tú por 13 años'. Él se enfadó, porque ha dejado la vida allá: '¡Ah! Quédate en casa. Ya estuve yo suficiente tiempo allí".

(FM I Z 676-682)

9 Se trata de seudónimos para mantener el anonimato de los entrevistados. 
La resistencia del padre se comprende en parte por la dureza de la experiencia de migración, que en su caso, y en el de muchos compatriotas de su tiempo, implicaba años de separación familiar excluidos los períodos de vacaciones. Este modelo individual caracterizó la emigración yugoslava a Austria en el período desde fines de los 60 a fines de los 80 y, en la mayoría de los casos, fue protagonizado por hombres jóvenes ${ }^{10}$. Dicho modelo respondía al deseo por parte del país receptor de establecer un principio de rotación a fin de evitar que la población inmigrada se estableciera definitivamente en Austria. Esta intención era compartida por los inmigrantes, cuyo objetivo era volver a su país lo antes posible ${ }^{11}$. Otro motivo sumamente importante que explica las resistencias paternas es la lógica familiar, pues, como se verá, la ausencia del hijo suponía mandar al traste el sistema de apoyo tradicional entre generaciones.

A diferencia del padre de Marko, los Miric no planearon una emigración individual. Tras una fase corta de unos meses de tanteo emprendida con su suegro, Marko regresó al pueblo y el matrimonio decidió emigrar quedando los hijos por el momento repartidos en las casas de los abuelos. Años más tarde, una vez estabilizada la situación laboral del matrimonio, se les unieron los hijos, aún de corta edad.

La decisión adoptada por el matrimonio Miric responde a un modelo de migración laboral. El deterioro de las perspectivas vitales en la región de origen hizo que la idea de cambiar de país fuera madurando como posible alternativa. Este punto contrasta fuertemente con la biografía de familias también oriundas de la antigua Yugoslavia y refugiadas por motivos políticos a quienes se entrevistó en el marco de la misma investigación. Estas se vieron obligadas a abandonar su país prácticamente de la noche a la mañana, cuando se presentó la ocasión de hacerlo. El cambio de país resultó en estos casos más abrupto puesto que no fue proyectado y por ello supuso una cesura biográfica más traumática. El matrimonio Miric tiene, además, un precedente migratorio en la generación anterior. Pero ante sus ojos la emigración aparece ya claramente como un proyecto al menos a medio plazo, por eso la familia no se quiere separar.

El caso de la familia Miric refleja con toda claridad ciertas líneas comunes de los procesos migratorios actuales. En general la tendencia a abandonar el

\footnotetext{
10 Cfr. Lichtenberger (1982).

11 SAYAD (1991), p. 63.
} 
propio país aumenta en la medida en que:

1. las personas se sienten inseguras, sea por razones económicas, sociopolíticas o ecológicas,

2. tienen la certeza, o al menos la fuerte convicción de que ellos o al menos sus hijos podrían vivir mejor en otro lugar,

3. poseen el valor de abordar el doble riesgo de emigrar-abandonando su ámbito vital conocido- y de inmigrar -volver a empezar en un contexto social nuevo en el que con mucha frecuencia la lengua, y en todo caso las leyes e instituciones, la organización social van a ser diferentes.

Estos tres factores remiten claramente a ciertos aspectos estructurales decisivos del hecho migratorio:

* El carácter forzado de la migración ${ }^{12}$. Si bien pueden establecerse determinadas diferencias entre las biografías de las personas exiliadas o refugiadas por motivos políticos y las de quienes emigran por motivos laborales, y a pesar de que estos últimos, a diferencia de los refugiados suelen desarrollar un "proyecto migratorio"13 (es decir, programan su desplazamiento y definen unos objetivos personales y familiares), sería totalmente erróneo pretender que tal decisión se ha tomado con libertad. La gente no suele emigrar si no es por imperativos vitales, entre otras muchas razones porque los costos son muy elevados.

* El au mento de la pobreza y dela riqueza en la UE dentro deun mundo en el que las comunicaciones y los medios de transporte van siendo cada vez más accesibles ${ }^{14}$.

* La selección social ocasionada por la migración: los más dotados, los más sólidos psíquicamente son quienes se atreven a correr el riesgo de abandonar su mundo conocido. Sin embargo, una vez que esos "emigrantes ancla" se han establecido en el país de acogida, aunque sólo sea con su presencia, animan a otras personas (de la familia, del vecindario, del circulo de amistades) a emprender la aventura de emigrar. De este modo se origina el fenómeno de la migración en cadena.

\footnotetext{
12 Butterwegge (2000), p. 274.

13 Pumares (1996), p. 158.

14 EUROSTAT (2000), p. 95.
} 


\title{
1.2.4. Vida en el país de origen
}

La casa

La familia procede de una región en la que la casa tiene un gran significado no sólo económico -como centro de la labor rural- sino también simbólico, como centro de continuidad de la vida familiar y lugar donde se verifica un pacto de asistencia recíproca entre las generaciones. Marko expone lo siguiente refiriéndose a su hija J anica:

\begin{abstract}
"Ya le he dicho.Cuando empieces a trabajar entonces tendrás que preguntarme: '¿Tienes dinero suficiente para hacer algo en casa?' Ahora sigo yo, pero cuando empieces tú, entonces tú tendrás que ahorrar y yo te daré algo más. Yo tengo ya suficiente. Así hacemos nosotros: todos vivimos en la misma casa. Yo, ella, mi hijo, mi mujer. Ella no necesita una casa. Ya tiene una. Y cuando yo sea viejo, recibiré su apoyo y por eso no necesito tener una jubilación. Así hacemos nostros. Tú sigues viviendo con tus hijos".
\end{abstract}

(FM I Z 477-486)

En esta región, tras la boda, las nuevas parejas se instalan en la casa de los padres del novio o de la novia sin que ni en los Miric ni en sus vecinos parezca existir una preferencia por la línea materna o paterna -como ha sido tradicional en el modelo familiar del sudeste de Europa ${ }^{15}$. A qué casa se va, afirman los entrevistados, depende del número de hijos que tenga la generación anterior. Lo importante es que los padres no se queden solos. Tan es así que en los primeros años de ausencia del matrimonio Miric en Austria, los abuelos se repartieron a los nietos. Tampoco a la hora del legado de bienes a los hijos se percibe una prioridad del matrimonio Miric por la línea masculina. De común acuerdo han decidido que la hija mayor herede en su día la casa paterna en el pueblo y el hijo menor la materna. Sin duda en este caso concreto el deseo de mantener las casas familiares es más fuerte que las tradiciones patrilineales que sí se perciben muy vivas en otras narraciones, concretamente de emigrantes del Kosovo. También es posible que el modelo familiar tradicional haya ido sufriendo una erosión ${ }^{16}$ al menos en la región de la familia Miric a lo largo del siglo XX y en concreto en el periodo del régimen de Tito.

La inversión en la casa aparece como una manera de garantizar el futuro de la siguiente generación que, pase lo que pase, siempre dispondrá de un

\footnotetext{
15 KASER (1995), pp. 175 y ss.

16 Op.cit., p. 450.
} 
techo. Por otra parte, al recibir la casa paterna, los hijos se comprometen implícitamente a seguir manteniendo ésta y a sus moradores, es decir, a garantizar la asistencia a los padres en la vejez.

La valoración de la casa en la localidad de origen resulta decisiva a la hora de elegir estrategias de inserción en el país receptor. Janica manifiesta:

“- (Janica) Cuando una piensa en cuánto han trabajado mis abuelos y quizá mis bisabuelos [por la casa]... ¿Y ahora sin más voy a venderla? ¿El lugar donde he pasado la mitad de mi vida? ¡No! No pienso venderla. O sea que la nacionalidad [austriaca] ni me la planteo en absoluto. De ningún modo

- (Entrevistadora) Ah ya ...

- (Janica) Bueno, si hubiera una doble, entonces sí la tomaría."

Austria es un país que no admite la doble nacionalidad y que se caracteriza por unas condiciones de naturalización particularmente duras en comparación con otros países de la UE ${ }^{17}$. Por lo tanto, los inmigrantes serbios que deseen adquirir el pasaporte austriaco, no sólo han de pagar una tasa elevada, como todo el mundo, sino que además han de renunciar a ciertos derechos ante el gobierno serbio, lo cual va unido a dificultades materiales para acceder a la herencia, si la hubiere. En el caso de esta familia, y concretamente de una chica que lleva la mayor parte de su vida viviendo en el país receptor, donde se ha escolarizado y donde ha adquirido un empleo fijo y cualificado, con todo la decisión de adoptar la nacionalidad austríaca se presentaba en 1999 con unos precios materiales y simbólicos demasiado altos. La vía de la doble nacionalidad hubiera permitido resolver un conflicto de intereses sin que los afectados tuvieran que verse en el dilema de renunciar a derechos políticos en el país donde viven y piensan seguir viviendo, o de renunciar a una cobertura material y emotiva ya existente. Tres años más tarde J anica ad optarála resolución de solicitar la nacionalidad austriaca, pero ello no puede interpretarse de ninguna manera como una decisión en favor del país receptor; los motivos son bien otros: habiendo entablado relaciones con un chico del pueblo, la única posibilidad de casarse y de vivir con él en el país receptor sin tener que esperar años es asumir la nacionalidad austriaca, dado que éste país es el único de la UE que establece cuotas para el reagrupamiento familiar de inmigrantes. Pocas veces se percibe con tanta claridad esa "atopía", esa vida entre dos polos de referencia a la que se refería Sayad.

17 CINAR (1999), pp. 67, 70. 
La dilatación de la estancia de los inmigrantes, su asentamiento definitivo en el país receptor y la permanencia de sus descendientes va contribuyendo a la formación de una población de edades diversas. Si bien la solidaridad intergeneracional no es de ningún modo una peculiaridad de esta población, la experiencia migratoria es responsable de ciertas particularidades. La edad en que una persona abandona su país, influye en su biografía. En principio, los jóvenes pueden adaptarse mejor que los adultos a nuevas situaciones, lo cual los convierte en "mediadores privilegiados"18 entre sus padres y la sociedad receptora. Pero por otra parte: "Cuanto más fuerte es la dependencia mutua entre generaciones, más fuerte resulta la transferencia cultural y étnica a la tercera generación, lo cual refuerza la co hesión familiar y también la proximidad cultural y emocional entre generaciones"19.

\title{
Relaciones de vecindad
}

Marko describe así su tierra:

\begin{abstract}
"Es un pueblo con 200 casas. Puede contarse unas cuatro personas por vivienda, o sea unos 800 habitantes. Yo conozco a todos por su nombre y apellido. El de ella [su mujer] es un poco mayor, 480 ó 500 casas; ella no conoce a todos por su nombre. Pero yo conozco a cada uno, casa por casa"
\end{abstract}

(FM IZ 533-538)

Este comentario manifiesta un contacto intenso entre vecinos que no se reduce a un mero conocimiento, sino que se traduce en un intercambio constante de servicios y prestaciones que se perpetuarán tras la inmigración en el país receptor. Hay que tener en cuenta, además, que en el reducido ámbito de origen de la familia Miric, las fronteras entre vecindad y parentesco son sumamente porosas. Y ello en una población cuya noción de familia -como sucede a muchos otros emigrantes- bien poco tiene que ver con la familia nuclear típica del modelo de Europa occidental ${ }^{20}$, como se desprende de las descripciones de fiestas así como de otros comentarios relativos a la estructura familiar (a los que en este artículo se ha renunciado por motivos de espacio).

\footnotetext{
18 Camilleri (1996), p. 52.

19 Dietzel-Papakyriakou (1993b), p. 191.

20 Ver una comparación entre este modelo y el de la familia extensa en: Mitterauer (1990), pp. 26-30.
} 
Las prestaciones que la familia enumeró a lo largo de las entrevistas parecían afectar más a los varones que a las mujeres. Estas aparecen en segundo término, más bien como sostenedoras de la red de relaciones a través de contactos y de visitas. En el pueblo, ese mutuo apoyo se muestra particularmente a la hora de construir una casa. La familia propietaria ha de comprar los materiales, pero el trabajo se realiza con ayuda del vecindario. Sin embargo, en los últimos años esta costumbre ha ido declinando debido a la despoblación del valle a causa de la emigración:

"Pero allí abajo se han marchado todos. Por eso tengo que pagar a extraños que vienen de muy lejos, $60 \mathrm{~km}$ o así"

(FM IZ 1190-1191)

La distancia geográfica equivale a distancia social: Ios vecinos trabajaban gratis, pero la gente que viene de fuera ya no está integrada en el sistema de relaciones de la localidad. Se entra así en otro sistema caracterizado por relaciones estrictamente laborales. También es interesante la percepción de lejanía:si bien todos los miembros de la familia Miric se identifican con Serbia y se sienten yugoslavos, su punto de referencia vital no es la nación -un país por otra parte no muy grande hoy en día- sino el valle y la red social de los habitantes de los tres pueblos. Esta fuerte identificación con el lugar de origen como primer punto de referencia se encuentra también en otra familias entrevistadas procedente de un ámbito rural (noreste de Bosnia), pero falta en otras familias entrevistadas procedentes de ámbitos urbanos (Mostar, Sarajevo), así como en familias de otras procedencias cuyos miembros tienen un nivel de estudios alto.

En el caso de la familia Miric aparece particularmente interesante el fenómeno de la reconstrucción de los antiguos lazos de asistencia recíproca entre vecinos en el nuevo contexto del país receptor. Refiriéndose a un vecino del pueblo, Marko relata:

\footnotetext{
"A este también le he hecho la casa. Es mi oficio. Él ha ido hoy con su coche y mi hija a recoger nuestro equipo estéreo porque yo estaba trabajando. Lo ha hecho libremente ¿No nos ayudamos todos? Yo también puedo trabajar dos días para él sin recibir nada. Pero sé que él también está dispuesto a ayudarme si lo necesito. Y así. Así somos. Estamos acostumbrados a la ayuda. Mi padre construyó su primera casa con ayuda (...) Y así estamos acostumbrados a hacer allí abajo [el pueblo]."
}

(FM IZ 1172-178, 1181)

La migración en cadena parece ser un presupuesto fundamental para la perpetuación de estas pautas de conducta en un nuevo contexto social. Como se verá más detalladamente, la mayoría de los habitantes del valle en 
cuestión, excluidas las personas mayores y algunos pocos niños, han ido emigrando a lo largo de las tres últimas décadas. Un grupo grande vive en Viena y su entorno, otros marcharon al Tirol y otros se instalaron en ciertas localidades de Dinamarca y de Holanda. Estas informaciones las suministró la propia familia Miric. A lo largo de las diferentes entrevistas, todas ellas colectivas (Marko, Svetlana, Janica y Goran, este último aún soltero), así como durante el último encuentro en el que invitaron a otras parejas de vecinos y conocidos, tuvimos ocasión de comprobar que el círculo de familias conocidas, no sólo en Viena, sino en los otros puntos indicados, era muy amplio. Todo ello, así como el hecho de que Marco y Svetlana eligieran como punto de inmigración el lugar dondehabía vivido el padre deaquél, está revelando el fenómeno de la migración en cadena.

Inmigrar es tomar una decisión arriesgada, por ello su realización rara vez se confía al azar. Muy pocas personas, la mayoría de ellas refugiadas políticas que tuvieron que abandonar su país inesperada y precipitadamente, llegan al país receptor sin disponer de contactos en éste. Para los recién llegados resulta decisiva la relación con familiares y conocidos, representantes de organizaciones no gubernamentales, asistentes sociales de organizaciones privadas y públicas así como representantes de comunidades religiosas. De todos estos contactos, los más importantes son sin duda los familiares, como se muestra repetidamente en las narraciones y entrevistas. Pero también la presencia de gente de confianza, como antiguos vecinos y conocidos, es un factor fundamental. En el caso de la familia Miric, procedente de un entorno social caracterizado por fuertes lazos de vecindad, resulta interesante observar cómo esa red de apoyo se ha trasladado al país receptor. Los servicios tradicionales se han modificado, pero no la red como tal ni la concepción de las relaciones de vecindad, aunque en el país receptor esa vecindad resulte reconstruída, remitida a la comunidad de origen.

El ejemplo de la familia Miric parece mostrar que la solidaridad entre familiares y vecinos en circunstancias duras, pervive sobre todo allí donde existe una tradición vívida de tales pautas de conducta. De todos modos ésto no implica una imagen ideal dela vida familiar o delas relaciones de vecindad. En estas redes sociales se producen conflictos y choques de intereses de manera parecida a los que surgen entre familias nucleares y su entorno social. La diferencia está en la organización social. Probablemente no sólo el ámbito rural, sino también el mayor o menor peso del Estado, explica este tipo de organización. De hecho, el modelo de familia nuclear presupone un Estado desarrollado y una vida social diferenciada. Poblaciones que se han 
organizado durante generaciones sin gran apoyo de la administración, parecen reforzar la solidaridad de las redes primarias. Sea como fuere, es indudable el carácter protector de dichas redes. Pero cabe preguntarse si el refuerzo de minorías étnicas a la larga no puede acarrear también efectos negativos para sus integrantes.

\subsubsection{La vida en el país receptor}

Roles de género y biografía laboral

Marko y Svetlana describen sus primeros años de vida en Austria como un trabajar sin descanso "sin parar un segundo en casa". Ambos desarrollaron diferentes biografías laborales. Cuando ellos Ilegaron a Viena, la legislación austríaca aún no era tan restrictiva como se ha ido volviendo a partir de la ley de 1993 y, sobre todo a partir de su actualización en 1997. Entonces aún era posible entrar en el país y trabajar en la economía sumergida para, algún tiempo más tarde, adquirir el permiso de trabajo, cosa que hoy en día es irrealizable, pues como medio de combatir las redes clandestinas, el gobierno austríaco niega hoy dicho permiso a quienes son sorprendidos en ocupaciones no declaradas.

A su llegada a Austria el matrimonio desarrolló una estrategia laboral encaminada a procurar la inserción legal en el mercado de trabajo, primero Marko y luego Svetlana. Ésta garantizaba unos ingresos mínimos para el matrimonio mientras su marido intentaba obtener el permiso laboral. Entonces el gobierno austríaco concedía los permisos laborales no a los inmigrantes recién llegados, sino a las empresas. La estrategia de Marko consistía en comenzar a trabajar en algún lugar -la ocupación era lo de menos- conformánd ose con unas condiciones laborales propias de la economía sumergida, es decir, claramente por debajo de las que disfrutan los ciudadanos del país ejerciendo la misma profesión ${ }^{21}$. La idea era demostrarle al jefe de empresa su valía, para de este modo hacerse acreedor anteéste de un permiso laboral. Mientras, Svetlana garantizaba unos ingresos fijos mediante ocupaciones en la economía sumergida. Esta estrategia explica los contínuos cambios de ocupación de Marko, ya que abandonaba las empresas en las que no veía perspectivas de ocupación legalizada, pasando fases de paro hasta encontrar un nuevo empleo. Primero trabajó de cocinero, luego en una gasolinera,

21 Wroblewsky (1998), p. 132; Treibel (1990), pp. 86-96; Gächter (1998), pp. 115-116. 
más tarde de jardinero y después de mecánico, hasta que al fin obtuvo un permiso de trabajo como obrero de la construcción, y en esa profesión ha permanecido hasta hoy. Poco después su mujer obtuvo también el permiso de trabajo.

Todo el proceso duró 5 años e implicó una clara devaluación laboral. Hoy la aportación de ambos cónyuges al sostenimiento de la familia es parecida. El precio de la migración ha sido la renuncia a la ocupación profesional que ejercían antes de emigrar.

Tanto en el país de origen como en el receptor, Svetlana ha trabajado como ama de casa y además ejerciendo otras ocupaciones. La diferencia para ella ha consistido en una sobrecarga mayor a partir de la emigración, sobre todo en los comienzos. He aquí cómo describe un día de trabajo en los primeros años:

(Svetlana) "Siempre he trabajado sin parar un segundo en casa".

(Marko) “...Primero trabajó en una discoteca..."

(Svetlana) "Era la discoteca más bonita de Viena. El trabajo no era difícil. Y quien quiere trabajar... Yo estaba en la cocina en el turno de noche, de 10 a 5 de la mañana. Luego volvía a casa. Dormir un par de horas y cocinar para él y para mi padre. Después de comer iba a la discoteca a limpiar, como una mujer de limpieza. Luego otra vez a casa un par de horas, y luego al turno de noche."

(FM IZ 910-920)

La sobrecarga femenina está muy lejos de ser un fenómeno específico de la migración, pero en muchos caso, como en éste, se agudiza al cambiar de país. Por otro lado, ese "limpiar como una mujer de limpieza" está indicando un distanciamiento de un oficio y de una situación laboral que para Svetlana hasta entonces eran desconocidas. Sin embargo, en este matrimonio no se observa la frustración perceptible en otros que han sufrido ese proceso tan propio de la experiencia de emigración como es la devaluación profesional y que suele acarrear una devalución social. Inmigrantes con alto nivel de estudios, entrevistados en el marco de la misma investigación, manifestaban una fuerte identificación con la propia profesión. Esta forma parte de su identidad personal, de ahí que les resulte tan fuerte el perderla y tan satisfactorio, en algunos casos, poder recuperarla.

En otras familias de inmigrantes, la devaluación profesional en síno parece plantear problemas particulares, pero sí en cambio la experiencia de devaluación social y de aislamiento. Un psiquiatra con larga experiencia en el tratamiento de enfermedades psicosomáticas de inmigrantes, percibe no 
pocos casos de histeria entre mujeres, sobre todo entre las procedentes de regiones rurales de Turquía y con una edad media o avanzada. Lo que las enferma suele ser la combinación de un conjunto de factores provocados por el cambio de contexto social, tales como, por ejemplo, la pérdida del grupo de mujeres del pueblo, ver reducido su ámbito vital al piso, problemas con un marido que descarga sus frustraciones sociales en casa. De este modo, la exclusión masculina redunda en la femenina. La histeria surge como expresión de problemas por los que estas mujeres se sienten desbordadas así como de la falta de apoyo que encuentran para trabajar dichos problemas de manera consciente 22 .

En el caso de los Miric no aparecen apenas huellas de conflictos parecidos. Salta a la vista el valor funcional del trabajo: es lo que les hace posible vivir en Austria y, al mismo tiempo, mantener un contacto regular con el pueblo, en donde se sienten profundamente arraigados y en cuya casa siguen invirtiendo a lo largo de los años.

En su conjunto, el proyecto migratorio de los Miric aparece en todo momento como una iniciativa masculina, si bien asumida de común acuerdo. Respecto a la inserción laboral, los objetivos estaban claros y se han perseguido consecuentemente. Entre la cohesión familiar y el éxito se da, en este caso, un reforzamiento recíproco. En otros casos, la diferente suerte en el mercado de trabajo produce situaciones conflictivas cuando los papeles se invierten y el varón, que antes aportaba el único sueldo o el principal, queda en una situación de dependencia de su mujer. El análisis de parejas procedentes de diferentes países arroja indicios claros de relaciones entre insatisfacción laboral, modificación de los roles de género y dificultades de inserción social, sobre todo en los hombres.

El acceso al mercado laboral en condiciones que puedan garantizar el cumplimiento de las prescripciones legales y una estancia prolongada depende en gran parte de la posibilidad de obtener informaciones fidedignas y contactos personales, sobre todo si se tiene en cuenta que la gran mayoría de los inmigrantes al comienzo de su vida en Austria ignoran la lengua del país. Ese apoyo puede lograrse mediante contactos privados o bien por organizaciones. La gente con un nivel de formación más elevado suele consultar con asesorías de inmigrantes e incluso recurrir a instancias institucionales. De todos modos, el análisis de diferentes narraciones muestra

22 Fernández de la Hoz \& Pflegerl (1999), p. 19. 
que, si bien el nivel de estudios es un factor importante para orientarse en el mercado de trabajo, aún más importante es la capacidad de iniciativa personal, unida a la posibilidad de recurrir a familiares y conocidos.

Si en una pareja es el hombre, la mujer o ambos quienes buscan trabajo, depende en esencia de los valores y las actitudes familiares y a la vez de las condiciones de vida imperantes en la sociedad receptora. En general las actitudes familiares se modifican lentamente, de manera que en las familias en las que el varón ha sido cabeza de familia y aportado el único sueldo o el principal, esa fórmula suele permanecer. En ocasiones las circunstancias llevan a reorganizar la vida familiar y laboral de acuerdo con nuevos criterios. Así por ejemplo, en algunas familias refugiadas procedentes de la antigua Yugoslavia y con unos roles de género tradicionales, las consecuencias inmediatas dela guerra alteraron dicho esquema. El varón tuvo que quedarse en su país como combatiente mientras la mujer, los hijos y en algunos caso otros parientes mayores, pudieron escapar. A partir de su llegada a Austria, las mujeres asumieron tareas que antes sólo habían incumbido a sus maridos, como, por ejemplo, asegurar el mantenimiento de la familia, ponerse en contacto con autoridades y otras instituciones, etc. En otras parejas en las que tanto el varón como la mujer asumían responsabilidades fuera del hogar, el papel representado después de la inmigración ha dependido de las posibilidades concretas que se les han abierto en el país receptor. En una pareja de Mostar en la que el marido trabajaba de electrotécnico y la mujer era jefa de departamento en un hospital, la cesura migratoria ha supuesto para la mujer la desvinculación del mercado de trabajo. A diferencia de su marido, para ejercer su profesión en Austria se vería obligada a convalidar su título. La edad ( 45 años) y el desconocimiento del idioma convierten ese objetivo en prácticamente inalcanzable, teniendo en cuenta, además, que se trata de una profesión saturada en el país receptor.

Con la nueva legislación austríaca a partir de 1997 se ha vuelto más difícil la incorporación al mercado de trabajo de los cónyuges inmigrados -la mayoría mujeres- mediante la fórmula del reagrupamiento familiar, ya que sólo después de cuatro años de permiso de residencia se les concede el permiso de trabajo. Por eso muchas de estas mujeres buscan ocupación en la economía sumergida, generalmente como asistentas privadas, para poder aportar un ingreso en la familia. De todos modos no se ha realizado aún ningún estudio que permita conocer el alcance de este fenómeno. 


\section{Vivienda}

Los Miric llegaron en un principio con la intención de repetir el modelo migratorio de la generación anterior: ahorrar lo más posible durante una estancia que se pretendía limitada a unos años, para luego volver a su localidad y reiniciar allí la vida gracias a los bienes acumulados. La diferencia estriba, como se ha visto, en que ellos iniciaron la migración en grupo, primero el matrimonio y luego, tras estabilizar su situación, hicieron venir a los hijos. Este carácter pretendidamente provisional explica el hecho de que en los primeros años ellos, como tantos otros inmigrantes, alquilaran una vivienda pequeña, lo más económica posible. El dato revela cuán falsa es, en muchos casos, una opinión ampliamente extendida según la cual los inmigrantes, a pesar de tener que asumir condiciones de vivienda por debajo de los estándares de la población receptora, mejoran de situación al inmigrar. Para muchos de ellos, asumir las condiciones de vivienda en Austria implica aceptar un empeoramiento respecto a la vivienda del lugar de origen, si bien éste se acepta debido a las prioridades establecidas en el propio proyecto migratorio ${ }^{23}$.

Sólo al cabo de 15 años de estancia los Miric se decidieron por alquilar una vivienda más amplia y confortable. Durante este período de tiempo, el retorno del matrimonio antes de la jubilación se ha ido haciendo cada vez más inviable entre otras razones a causa de la emigración generalizada de la población del valle. Ello ha producido una modificación en la estructura socioeconómica de la zona. Las explotaciones agrícolas familiares se han ido abandonando, pero muchos vecinos vuelven a sus casas en los períodos de vacación de manera que esa pequeña región florece en Navidad y en verano, particularmente en el mes de julio. Por otra parte, la escolarización de J anica y Goran ha tenido lugar en Austria, país en el que ambos trabajan hoy. Estos hechos han producido una modificación del proyecto migratorio familiar. El futuro ya no aparece claramente dibujado, los miembros de la familia manifiestan deseos diferentes:

(Entrevistadora) "Si pudieras soñar, ¿qué desearías para tu futuro?

(Janica) ¿Para mi futuro?

(Entrevistadora) ¿Austria? ¿El pueblo?

(Janica) ¡No, no! Pero mi país sigue siendo Yugoslavia, eso es seguro.

23 Pflegerl \& Fernández de la Hoz (2001), p. 47. 
(Svetlana) Ya se lo he preguntado y quiere vivir allí... Yo podría vender la casa [del pueblo] al tomar la nacionalidad [austríaca]. Pero ella dice: 'Puedes vender lo que quieras, pero no mi casa'.

( Marko) La primera vez busqué un piso en propiedad. 'OK. - pensé- Pago mucho, y así ella y su hermano tienen un piso más grande; así pueden compartirlo si yo vuelvo algún día, o si me muero'. Pero yo no quiero ningún piso en propiedad. ¿A quién se lo dejaría? Sólo para venderlo y ganar dinero, no vale. También les he propuesto trasladarnos un poco hacia las afueras de Viena: 'Si quieres vivir en Austria, busquemos una casa'.

(Janica) Mi país sigue siendo Yugoslavia."

(FM IZ 1823-1835 y ss.)

En este pasaje la actitud de los padres aparece más abierta, indefinida que la de la hija. Sin embargo, a pesar de que ésta insista en su vinculación con el pueblo, no descarta en absoluto seguir viviendo en Austria. El valor de la casa en el lugar de origen puede explicarse por razones históricas y de tradición, pero es muy probable que dicha tradición se esté reforzando con un valor simbólico nuevo: el punto de referencia emotivo de quien ha emigrado.

\section{Formas de inserción}

Independientemente del tipo y la calidad del tratamiento sociopolítico que reciban, los inmigrantes no son objetos pasivos, sino sujetos con intereses, proyectos y capacidad de reacción ante las condiciones de vida, las personas y las instituciones que encuentran en el país receptor. El comienzo en un nuevo entorno social les lleva a reorganizar su vida. Con ello, de un modo o de otro, se insertan en el país receptor. En el transcurso de la investigación llevada a cabo entre 1997 y 1999 sobre familias inmigrantes procedentes de la antigua Yugoslavia y de Turquía se pudieron observar diferentes estrategias globales de integración ${ }^{24}$. Así por ejemplo, hay familias cuyos miembros se van identificando poco a poco con el país receptor manteniendo, al mismo tiempo, fuertes contactos con el de origen. Su red de relaciones en Austria es compleja y abarca tanto personas de uno como de otro ámbito. Sus miembros han ido desarrollando una "identidad crítica"25.

J unto a estos grupos familiares existen otros que se insertan en comunidades étnicas con un marcado carácter territorial, concentrándose en un

\footnotetext{
24 Pflegerl \& Fernández de la Hoz (2001), p. 77-83.

25 Camilleri (1996), p. 68.
} 
edificio, una calle o un barrio y procurando reproducir lo más fielmente posible las condiciones de vida de la localidad de origen, lo cual, evidentemente, más que una reproducción constituye una reconstrucción, dado que la localidad y el país de origen siguen evolucionando durantesu ausencia. Los miembros de estas comunidades suelen entrar en contacto con gente del país receptor a través del mercado de trabajo y de las instituciones (sanitarias, escolares, administrativas, etc.). El resto del tiempo se vive en la comunidad étnica. Los nuevos medios de comunicación y su abaratamiento facilitan las visitas regulares -durante los períodos de vacaciones- a la localidad de origen sobre todo a aquellos inmigrantes que, poseyendo ya un permiso indefinido de residencia y gozando de una situación laboral estable, no temen complicaciones al abandonar el país receptor. Por otra parte, la televisión vía satélite garantiza un contacto permanente afectivo y efectivo con el país de origen y colabora a reforzar la lengua materna. Dichos medios están representando un papel decisivo en la cristalización de nuevas formas de inserción. Por una parte ayudan a paliar el desarraigo de muchos inmigrantes. Por otra, pueden colaborar a cimentar el aislamiento respecto a la sociedad receptora.

La familia Miric y sus vecinos presentan algunos rasgos de estas comunidades étnicas, pero con ciertas particularidades. La más interesante es la ausencia de una concentración territorial:

(Entrevistadora) “ ¿Hay mucha gente de esa región en Austria o en Alemania?

(J anica) En muchos sitios. En Alemania, en Suecia ... (...) Australia, Dinamarca, Suiza, Austria, Alemania...

(Marko) ... Holanda".

(FM IZ 313-314; 318-321)

Los Miric y sus vecinos han ido definiendo claramente sus ámbitos vitales. Surgen así un modo de vida cada vez más estable y una mentalidad pendular: el país receptor es el lugar de trabajo y de vida cotidiana. La localidad originaria es el centro vital en el que se invierten recursos económicos y tiempo. Allí se vuelve cada año y en esos períodos fijos de vacación tienen lugar los acontecimientos sociales, particularmente las bodas. De este modo, la localidad de origen se reconstruye y se convierte en lugar simbólico en el que los antiguos vecinos se sienten arraigados, protegidos y refuerzan unos lazos sociales que se perpetúan en el extranjero. De hecho, los Miric mantienen contacto regular a través de llamadas telefónicas y de visitas no sólo con una veintena de familias que hoy viven en Viena, y con las que, como se ha 
visto, el intercambio de servicios es acusado, sino también con otras en otros puntos del país así como en otros estados de la UE (Holanda y Dinamarca).

Cristaliza así una comunidad de diáspora de tipo nuevo. Si las comunidades de diáspora ya conocidas, ( por ejemplo, chinos en los EEUU, vietnamitas en Bélgica) se explican por la lejanía geográfica y cultural de los emigrados, este nuevo tipo parece surgir principalmente de la confluencia de dos factores: por un lado la existencia de una comunidad muy claramente definida y con un alto grado de cohesión, y por otro, paradójicamente, la cercanía geográfica unida a un abaratamiento del transporte, que hacen posible una vida pendular estable y organizada.

Dentro de esta comunidad se va formando incluso un mercado matrimonial propio:

(Janica) “¿Si quisiera casarme? Ahora es difícil decirlo si se busca a alguien que no vive en Yugoslavia. Si vive en Yugoslavia... no se le puede traer. Yo tengo un par de amigos que viven aquí y sus mujeres en Yugoslavia. Tienes que buscar en Dinamarca o así, un sitio a donde yo pueda ir. 0 que él esté en Austria y yo lo pueda hacer venir aquí para estar juntos (...) Tirol, Salzburgo (...) Si él estuviera en Dinamarca habría posibilidades de ir allí. Pero aquí en Austria no existe la menor posibilidad.

(Marko) Ahora con el Schengen ha mejorado algo la cosa ...

(Entrevistadora) Pero entonces, si te he entendido bien, tú buscarías entre la gente que conoces de tu valle, pero que están en otro sitio ...

(Janica) ¡Sí! O sea, la mayoría ya no viven en Yugoslavia. Están en el extranjero. Pero a mí no me gustaría casarme con alguien que no vive en mi región. (...) Belgrado está muy lejos; los chicos de allí no me interesan.

(Svetlana) ... muy lejos ...

(Janica) No sólo muy lejos. Piensan de otra forma. Y ya sé. Si me quisiera construír una casa en Yugoslavia, él diría: '¿Para qué queremos eso?' O: 'No la quiero' Y esto y lo otro. (...) Por eso no quiero. Es decir [buscaría un chico] de mi zona. Los de Belgrado no son del pueblo, son de una ciudad."

(FM IZ 586-620)

Esta opinión ha sido corroborada con los hechos. Su hermano Goran se ha casado en 2000 con una muchacha de una familia del pueblo y J anica, como se ha mencionado ya, se ha prometido en 2001 con un muchacho también de allí.

Cabe preguntarse si este tipo de comunidad de migración se irá diluyendo a lo largo del tiempo o mantendrá su cohesión. La respuesta no es clara. En todo caso, plantear hoy la situación de los inmigrantes en términos del 
clásico dilema "volver o quedarse", no parece apropiado. Desde esta perspectiva se corre peligro de perder de vista las repercusiones que las nuevas condiciones materiales de vida pueden tener en las formas de inserción.

Según Sayed, tanto inmigrantes como gente del país receptor vivimos con tres ilusiones fuertemente arraigadas: la ilusión de una presencia necesariamente provisional; la ilusión de que esa presencia se explica únicamente por razones laborales; la ilusión de la neutralidad política, es decir, la presencia de los nuevos habitantes no ha de modificar las estructuras de poder o la organización de la convivencia ni en el país deorigen ni en el receptor ${ }^{26}$. Vidas como la de los Miric muestran los complejos procesos que la migración provoca no sólo en quienes la emprenden, sino en los países de acogida. Pretender que tanto la sociedad de emigración como la de inmigración no se modifican por estos procesos, resultaría ingenuo, por mucho que aún ignoremos el desarrollo ulterior de ciertas estrategias deinserción, como por ejemplo, la de la comunidad de diáspora descrita.

\section{Quienes no emigran: poblaciones de los países receptores}

Las paradojas referentes a los países receptores pueden encontrarse en los diferentes ámbitos de la vida social. Todos ellos están estrechamente ligados entre sí y se alimentan recíprocamente. Es decir, las condiciones que encuentran los inmigrantes en el mercado laboral o de la vivienda están íntimamente relacionadas con su situación política o con las actitudes predominantes hacia los extranjeros, las expectativas de vida, las frustraciones o los temores de dicha población tienden a reforzar determinadas líneas de actuación -o inhibición- política. A largo plazo puede descubrirse una dinámica de refuerzo recíproco entre las estructuras y formas estables de organización de un país, elementos, por así decir, "externos", observables a partir de las instituciones, normas y costumbres en que cristalizan, y otras estructuras, las "internas"; éstas últimas están constituidas por las formas de sentir, percibir y pensar de individuos y grupos, y por ello resultan más difíciles de aprehender, debido a la existencia de contradicciones y también al hecho de que dichas formas de sentir, percibir y pensar, no necesariamente se expresan de manera inmediata en obras o palabras. A continuación se hará referencia a tres de esos ámbitos: el del conocimiento, el de la opinión pública, y el de la política.

26 SAYAD (1991), p. 18. 


\subsection{Las explicaciones del hecho migratorio}

Uno de los rasgos de la cultura racional europea es la búsqueda de la objetividad. El valor de esta actitud es indudable, ya que sin ella no se hubiera originado la ciencia. Sin embargo, la búsqueda de la objetividad hecha rutina ocasiona no pocas dificultades en el ámbito de las ciencias humanas, dado que, de hecho, la realidad social o las personas observadas -objetivadasnunca puede separase de quien las observa. Percibir a los otros nunca es un acto meramente óptico, sino que implica los propios intereses, las propias actitudes y valoraciones, tanto las conscientes, como las internalizadas espontáneamente en el entorno social. Por otro lado, la mirada lejana tiende a ordenar a los otros según categorías fijas, y por ello fácilmente pierde de vista el hecho de que los otros cambian. No es casualidad, por ejemplo, el amplio eco que hoy encuentran en la UE explicaciones culturalistas.

Cabe verificar un cierto retraso en la percepción de los migrantes. A pesar de los considerables progresos realizados respecto al conocimiento de los procesos migratorios, a veces se tiene la sensación de que las teorías clásicas, los métodos de investigación y el vocabulario establecido se han vuelto odres viejos que hacen aguas si se intenta meter en ellos la complejidad y los procesos acelerados de cambio de nuestras sociedades actuales: "De hecho la migración es difícil de definir, complicada de medir, polifacética y multiforme y se resiste a la teorización (Arango 1985)", y es "opaca al razonamiento teórico en general y a los modelos formales en particular" (Davis 1988, 245). Los dos primeros obstáculos crean ambigüedad y dificultan la operatividad; el tercero requiere enfoques interdisciplinares que raramente se dan ${ }^{27}$. A ello hay que añadir una multiplicidad y diversidad de conocimientos acerca de los migrantes en los países de la UE. Dicha pluralidad de enfoques se debe a factores tales como las diversas tradiciones sociológicas, o la diferente antigüedad de los procesos migratorios.

El primer indicador de un desfase entre las explicaciones de los procesos migratorios y la realidad de los mismos, se encuentra en el vocabulario, que tantas veces suele adolecer de inadecuado. A una persona que lleva años viviendo en un país, no tiene por qué cuadrarle necesariamente el calificativo de "extranjera" -acepción que encima, en las lenguas románicas, está emparentada con "extraña"-. "Extracomunitario" constituye un neologismo pseudo-jurídico aparentemente neutral que sólo define a la gente por lo que no

27 Castles (2000), p. 45. 
es y que de ningún modo se adecua a describir la complejidad de la experiencia de la migración.

Debido a su valor histórico como ejemplo claro de una determinada manera de entender la migración, la palabra "Gastarbeiter" es conocida más allá del área de habla alemana. "Trabajador huésped", es un claro eufemismo por el que se designaba alguien que está de paso cumpliendo una función laboral, pero que al cabo de unos años volverá a su casa, como hicieron entre fines de los 70 y comienzos de los 80 tantos españoles y españolas. El principio de rotación, establecido hace cuarenta años por los países más desarrollados de Europa, se basaba en el primado de los intereses del mercado, y del país receptor. Éste requería mano de obra joven, barata, sobrecargable, y fácilmente sustituíble por otra. La sustitución era un elemento importante en orden a ahorrar costes de infraestructura y quebraderos de cabeza políticos. Si los inmigrantes se quedan, fundan o hacen venir sus familias. Y una población estable reclama escuelas, vivienda, asistencia sanitaria y social, etc. La incorporación de esa sociedad estable plantea también la cuestión de los derechos de sus miembros. Estas cuestiones han comenzado a plantearse con notable retraso y el término "Gastarbeiter" ha ido cayendo en desuso. Al parecer se ha terminado por verificar que "el huésped se queda"28. Sin embargo, las connotaciones de la palabra parecen sobrevivirle en la medida en que no se asume la durabilidad eirreversibilidad de los procesos migratorios, o en la medida en que los análisis se plantean desde la perspectiva de los inmigrantes en cuanto huéspedes, que están pero que no son. Ello se delata en el empleo del vocabulario. Así por ejemplo, aún hoy es normal Ilamar "inmigrante" a niños y niñas nacidos en el país receptor, cuando esos pequeños jamás han vivido el único hecho constitutivo de la migración que consiste, justamente, en esa cesura biográfica que se produce al cambiar de entorno social.

También se habla de inmigrantes de "segunda" y hasta de "tercera" generación. Si duda alguna, estos términos resultan prácticos en el estricto ámbito de la sociología, dado que las perspectivas vitales de los descendientes de inmigrantes están relacionadas también con el factor tiempo. De todos modos, otros factores igualmente importantes como el género, están muy lejos de influir en la terminología más usual. Y en todo caso, al divulgarse los vocablos mencionados, se refuerza una determinada percepción de las

28 Título de la obra de LoYCKE (1992), cfr. 11-12. 
personas emigradas como portadoras de un carácter diferente y perdurable. El culturalismo está ya a un paso. Otro ejemplo de empleo paradójico de vocabulario es el recurso al término "países de acogida" que, como manifiesta Luigi Perrone, en muchos casos puede rayar en la hipocresía, habida cuenta de la acogida dispensada a los llegados ${ }^{29}$. Podrían citarse otros muchos casos. No obstante, una vez concluida la reflexión, no queda otro remedio que retomar esta terminología deficitaria aplicando las correcciones posibles y en todo caso prestando siempre mucha atención a los aspectos implícitos por referencia o por elisión. En el caso de vocablos normativos, muy particularmente "integración" y "exclusión" 30 , sería del todo ilusorio pretender la existencia de un acuerdo general en su contenido. Pero precisamente por ello conviene aclarar lo más posible qué se entiende cuando se argumenta en esos términos.

En cuanto a la temática, la mayoría de los trabajos hasta mediados de los años 90 han ido enfocados al conocimiento de los inmigrantes, y de éstos como objeto de tratamiento (estadísticas sobre la demanda del mercado de trabajo, estudios demográficos sobre los movimientos y la distribución de la población, monografías acerca de las actitudes hacia los migrantes, estudios sobre las condiciones de vida -legislación y marco socioeconómico- que encuentran en el país receptor): sólo en los últimos años se han ido acrecentando los trabajos que consideran la vida de los migrantes en su doble perspectiva de gente entre dos mundos y que los contemplan como sujetos activos, con sus intereses, sus emociones, sus reacciones, sus estrategias de inserción y sus proyectos. Dichos proyectos dejan de verse como mero indicador de intención de retorno, sino que pasan a esclarecer una multiplicidad de biografías. Desde esta perspectiva comienza a captarse la importancia de la vida familiar en el contexto de la migración.

El aspecto fundamental sin embargo, son las teorías a partir de las cuales se explica el fenómeno de la migración. Quienes sienten sus posibilidades de vida fuertemente deterioradas e incluso amenazadas, pueden tender a buscar nuevas posibilidades en otros lugares, siempre que se den ciertas condiciones de posibilidad. La información (saber que la vida en otros

29 Perrone (1995), p. 17

30 Fernández de LA Hoz, P. : Soziale Ausgrenzung und Familienleben in den EU-Ländern. Bericht an die Europäische Beobachtungsstelle zur sozialen Situation, Demographie und Familie: http://europa.eu.int/comm/employment_social/family/observatory/: 15.10.201. 
lugares podría ser mejor), la experiencia (conocer o tener referencia de quienes han dado el paso y han logrado salir adelante, sea por vías legales, o por canales de tráfico clandestino), la fortaleza psicológica (atreverse a emigrar), circunstancias extraordinarias (como el deterioro económico de la región donde se vive, o el temor por la integridad física propia o de los allegados más cercanos), son factores de motivación decisivos. Sin embargo, la pobreza, la inseguridad y la miseria no bastan para explicarse los procesos migratorios, dado que los movimientos de población de zonas pobres a zonas prósperas ni han funcionado en el pasado ni se producen hoy con la fluidez de unos vasos comunicantes ${ }^{31}$. De ahí la importancia de precisar otros factores.

En el contexto de los cambios socioeconómicos, políticos y culturales que suelen resumirse bajo el término de globalización ${ }^{32}$, se asiste a un aumento extraordinario de los intercambios materiales - productos, informaciones y servicios incluida la mano de obra: "La globalización ya es un hecho"33. Debido a la apuesta por una economía altamente desarrollada como medio de asegurar la prosperidad material y de actuar contra la exclusión social ${ }^{34}$ y también a su evolución demográfica ${ }^{35}$, los países de la Unión tienen necesidad inmediata tanto de mano de obra no cualificada como de mano de obra altamente cualificada que ya no están en condiciones de garantizar por sí mismos. A largo plazo necesitan también nuevos contingentes de población que resuelvan o al menos palien el crecimiento negativo de la Unión. Por otro lado, en los últimos años muchos países situados en la periferia de la Unión Europea o bien han vivido un estancamiento económico o bien han sufrido un claro deterioro de manera que su situación general se ha vuelto inestable. Lo mismo cabe decir respecto a países geográficamente más lejanos pero con fuertes con lazos históricos con países miembros de la Unión. Los procesos de polarización socioeconómica y la existencia de redes y estructuras de intercambio internacionales contribuyen decisivamente a alimentar y agudizar la dinámica migratoria.

\footnotetext{
31 Castles (2000), p. 36.

32 Butterwegge (2000), p. 274.

33 EUROSTAT, Memo 11/97, Juni 1998.

34 Comunidad Europea (2001b), p. 4. Ibid (2001a), p. 10.

35 EUROStAT (2000), pp. 12-13, 18-19, 46-47. Mejer (2000).
} 
En las tesis neoclásicas basadas en los modelos de "zonas de expulsión y de atracción" la migración se explica como resultado de un desfase entre la oferta y la demanda de mano de obra. Las diferencias salariales impulsan a la gente a abandonar su país en busca de espacios más prósperos y rentables. Desde esta perspectiva, la migración se presenta como el producto de una decisión individual. La consecuencia política es que los recién llegados son responsables de haberlo hecho. El pronóstico: cuando a los interesados deje de resultarles rentable la emigración, volverán a casa. Sin embargo, la realidad desmiente esta teoría. A pesar de que en los últimos años los costes humanos de la migración han aumentado, la migración no ha disminuido, lo que ha crecido han sido las redes ilegales. Otras teorías, como la del mercado de trabajo dual, la "new economics of Migration" o la teoría neomarxista del sistema mundial llegan a diferentes conclusiones y acentúan diferentes factores macro-estructurales. ${ }^{36}$ Por otra parte, hay que considerar la dinámica propia de la "migración en cadena": una vez establecidas redes de comunicación y relaciones estables entre inmigrantes, no cabe cerrar o abrir los flujos migratorios como se controla un fluido. Las personas pueden producir y ofrecer bienes, pero nunca pueden planificarse como tales. La conclusión es evidente: "There is nothing more permanent than temporary workers" ("Nada hay más permanente que los obreros temporales"). ${ }^{37}$ Otra cosa es que este hecho se asuma o no.

La pregunta ¿por qué emigra la gente?, por muy rudimentaria que parezca, ha de volver a plantearse hoy de nuevo, dado que las diferentes teorías abocan en praxis políticas diferentes. A esta cuestión han de unirse otras relativas no tanto a las causas de las migraciones, sino a las dinámicas de dichos procesos. Realidades como el deterioro sociopolítico de ciertos países periféricos, el carácter de las políticas de ayuda al desarrollo, el aumento de la competitividad a escala mundial y la demanda en los países de la UE de mano de obra, el fenómeno de la migración en cadena, el papel delos lazos familiares, las formas de inserción desarrolladas por los inmigrantes, y otros que sin duda aún no hemos llegado a percibir con claridad y que explican la génesis y dinámica de los procesos migratorios, no desaparecen por no nombrarlos. Antes bien, conducen a políticas mal orientadas y, en consecuencia, erróneas.

\footnotetext{
36 Parnreiter (2000). Castles (2000), pp. 38-40.

37 Philip Martin, citado por ParnReiter (2001), p. 4.
} 


\subsection{Percepción selectiva y negativa de la migración}

\subsubsection{Espejos de la sociedad receptora}

La migración, más que otros fenómenos sociales, es capaz de revelar la naturaleza de la sociedad de acogida. Sayad afirmaba que los migrantes representan el papel de un espejo en la producción de la reflexión científica y del sentir común, ya que, con su mera presencia, están obligando a sus interlocutores a manifestarse a sí mismos: las propias argumentaciones, el saber elaborado, el horizonte político reivindicado. Por eso: “Al hablar de los inmigrantes estamos hablando de nosotros mismos en relación a los inmigrantes" 38 .

\subsubsection{La migración como problema}

Toda esta variedad de biografías se desdibuja para dejar espacio en primer plano a una especie de retrato robot construido con trazos genéricos. La imagen acaba por querer referirse a todos y no representar a nadie. Además suele ser una imagen negativa, o al menos indudablemente problemática. Los aspectos positivos que puede implicar la inmigración como el enriquecimiento demográfico y social, la capacidad de generar puestos de trabajo merced a las propias iniciativas, y el hecho de que "en general la contribución y la riqueza humana de esta importante parte de la población mundial es ciertamente inmensa" 39 , apenas se perciben en los medios de comunicación, en la calle, 0 en las conversaciones cotidianas.

Los movimientos migratorios no constituyen en sí una novedad. Un país como España ha vivido en las décadas posteriores a la Guerra Civil fuertes flujos internos y también ha sido un país emisor de mano de obra hacia otros países europeos (Francia, Bélgica, Alemania). Por tanto, lo que más bien va cambiando son las direcciones y la complejidad de los flujos así como el hecho de que una gran parte de los inmigrantes y sus familias tienden a asentarse definitivamente en el país de acogida, independientemente de la intensidad de los contactos que sigan manteniendo con el país de origen. ¿Cómo reaccionan las poblaciones de los países de acogida a estos procesos?

\footnotetext{
38 Perrone (1995), p. 13.

39 Recolons (2001), p. 53.
} 


\subsubsection{Los países de la UE - Datos generales}

A partir de datos proporcionados por EUROSTAT, el Observatorio Europeo de los Fenómenos Racistas y Xenófobos (EUMC) ha presentado dos estudios sobre las actitudes de los europeos hacia los inmigrantes y las minorías étnicas. El primero, realizado en 1998, está basado en datos longitudinales; el segundo ha sido realizado en 2000 como complemento del anterior.

En el estudio longitudinal se percibía un aumento de las actitudes xenófobas en los países de la UE en el período comprendido entre 1989 y 1997 y, al mismo tiempo, un declive del interés por las cuestiones sociales ${ }^{40}$. “Un hecho que apenas es tomado en consideración, sino que más bien se evita afrontarlo"41.

Se trata de una xenofobia difusa que no suele presentarse articulada como doctrina racista en sentido estricto, pero que se encuentra fuertemente arraigada en un etnocentrismo caracterizado por "el repliegue sobre sí mismo, una mezcla de arrogancia e ignorancia, la intolerancia frente a normas culturales ajenas a las del propio grupo de pertenencia", que Taguieff denomina "racismo social"42, y que ha perdido su carácter "desigualitario" y biologista para asumir la forma de un racismo "diferencialista" de fundamento cultural ${ }^{43}$.

Si bien han pasado ya unos años desde este primer estudio, ciertas tendencias siguen siendo actuales. Así por ejemplo, en 1997 el $60 \%$ de los ciudadanos y ciudadanas de la UE opinaba que "hay demasiados extranjeros en el país", lo cual es manifiestamente un sentimiento y no una opinión fundada, ya que a menudo los datos reales y las valoraciones de los entrevistados no coinciden. Esta discrepancia entre percepción y realidad se repite en estudios de actitudes referidos a inmigrantes.

Un promedio de $71 \%$ de los entrevistados opinaba que "las minorías se encuentran discriminadas en el mercado de trabajo", pero ello no llevaba necesariamente a un mayor deseo de reformas sociales en favor de los

\footnotetext{
40 EUMC (1998), p. 64.

${ }^{41}$ EUMC (1998), p. 4

42 Taguieff (1998), s. p.

43 Mayer (1999), p. 55.
} 
afectados. Un 50\% aceptaba inmigrantes de países no miembros de la UE como mano de obra así como refugiados legales, pero con la condición de no ampliar sus derechos. La otra mitad de los entrevistados se dividía en dos grupos aproximadamente igual de numerosos, los unos por una mayor acogida de los inmigrantes, los otros en favor de una política migratoria más restrictiva. Incluso resulta significativo que, si bien el intercambio de población con otros países miembros de la UE no se ponía en cuestión, 49\%estaban de acuerdo con una apertura restrictiva.

En el período entre 1997 y 2000 se observa una evolución contradictoria. Por una parte muchos ciudadanos y ciudadanas de la UE se manifiestan claramente a favor de líneas políticas que favorezcan y mejoren la convivencia entre las mino rías étnicas y la población de los países receptores. Por otra parte, la mayoría de los encuestados teme que dichas minorías disturben la paz social y el bienestar. Este grupo se ha acrecentado entre 1997 y 2000. Junto a ellos, un grupo más pequeño pero significativo de encuestados se manifiesta personalmente molesto por la presencia de minorías. Lo que, en todo caso, aparece muy claro es que las personas que se muestran preocupadas por la evolución social o temerosas ante ella, no valoran el multiculturalismo ni ven en los inmigrantes un elemento enriquecedor de la vida social ${ }^{44}$.

El 25\% de los entrevistados identifica la integración de inmigrantes con su asimilación. Combinando los diferentes indicadores utilizados en este segundo estudio, puede construirse la siguiente tipología: si bien las personas "tolerantes activas" son más que las "intolerantes activas", el grupo más numeroso es el formado por la gente "tolerante pasiva" y "ambivalente", o personas que combinan en sí actitudes positivas y negativas. Este último grupo (25\%) es el más permeable a las actitudes de los dirigentes políticos.

En ambas encuestas la intolerancia frente a los inmigrantes aparece relacionada con ciertos factores. El temor a sufrir el paro, la experiencia de un empeoramiento de la situación personal, la definición política como "de derechas", una edad avanzada, un nivel de escolarización bajo y la falta de contactos personales con inmigrantes o sus descendientes, parecen relacionarse con sentimientos de xenofobia. De todos modos, en cuanto a la influencia de dichos factores, conviene proceder con cautela antes de generalizarlos, dado quealgunos de ellos -como por ejemplo, el ámbito rural

44 Thalhammer et al. (2001), p. 9. 
o urbano, la edad- presentan variaciones sustanciales según los países. La misma precaución procede a la hora de establecer relaciones de causalidad. En la encuesta de 1997, por ejemplo, no se pudo establecer correlación alguna entre la condición de paro laboral y la intensidad de actitudes xenófobas. Tales experiencias personales de crisis no producen, sino más bien actualizan y activan percepciones ya existentes, aunque sea latentes, en las personas afectadas ${ }^{45}$. Los miedos subjetivos parecen representar un papel mucho más importante que los acontecimientos objetivos, como se manifiesta en estudios sobre parados de larga duración ${ }^{46}$.

En cuanto al contacto con inmigrantes también se imponen algunas precisiones: del mismo modo que ya hace décadas se verificó la existencia de un "antisemitismo sin judíos", hoy también puede percibirse una "xenofobia sin extranjeros", lo cual es una clara prueba de la importancia dela dimensión emotiva en la estructura de los prejuicios sociales ${ }^{47}$.

Luxemburgo es el país con un mayor porcentaje de inmigrantes y sin embargo arroja los valores de xenofobia más bajos. Lo mismo sucede, por ejemplo, en Vorarlberg respecto a los otros estados federales austriacos. Estos hechos desmienten la falsa aunque divulgada idea de que el conflicto social se impone necesariamente allí donde hay pluralidad cultural. En general la falta de trato y el desconocimiento de los inmigrantes favorecen percepciones negativas. Pero, de todos modos, sería un error grave pensar que el mero contacto opera el efecto contrario. Éste puede exasperar y agudizar los problemas de la convivencia. Todo ello remite a la necesidad de ahondar las condiciones estructurales y personales en que dicha convivencia se produce.

Comparando monografías realizadas en los estados miembros de la UE pueden apreciarse algunos otros hechos significativos. Así por ejemplo, en algunos estudios estatales (Finlandia, Austria) ${ }^{48}$ se muestran actitudes muy diferentes respecto a las personas llegadas según busquen trabajo o asilo político. La disposición a la solidaridad parece aumentar cuanto más claro se

45 Ahlheim \& Heger (2000), p. 379.

46 Fernández de la Hoz \& Pflegerl (1999b), p. 384. Un estudio sobre simpatizantes del Front National francés realizado poco a antes de su escisión, muestra que los factores que favorecen la xenofobia no son prioritariamente económicos. MAYER (1999), p. 78.

47 Heckmann (1992), p. 123.

48 Lebhart \& Münz (1999), p. 40. Södering (1997), s. p. 
perciba el conflicto del que huyen los refugiados, cuanto más inequívocamente aparezca su estancia como provisional, cuanto más necesitados o inocentes aparezcan las víctimas de conflictos políticos (niños, mujeres). Ello es indicio de una solidaridad capaz de movilizarse a partir de hechos palpables. En cambio, las estructuras sociopolíticas que desencadenan procesos migratorios y marginan a quienes los protagonizan, son complejas, opacas y silenciosas.

\subsection{4. ¿Por qué estas actitudes?}

Según el equipo del EUMC estas tendencias valorativas se deben a la existencia de conflictos sociales en los países receptores -latentes o abiertos- y a la cristalización de crisis de identidad, todo ello unido a déficits políticos y a un tratamiento incompetente por parte de las autoridades públicas de la inseguridad y de los temores de la población de los países miembros de la UE ${ }^{49}$.

En los diferentes países en que sehan realizado estudios de actitudes hacia los inmigrantes aparecen indicios evidentes de la existencia de prejuicios xenófobos manifestados en juicios categóricos: "Ios X son violentos", "nunca se integrarán", "deberían casarse con la gente de su país", etc. Lo que varía según los países, es el grupo que tropieza con el mayor rechazo. En Francia parecen ser los musulmanes, en Alemania los turcos, en Austria quizá los africanos, en España los gitanos y norteafricanos ${ }^{50}$, en Finlandia los rusos. Cada sociedad parece generar sus propios espectros a partir de la propia historia, de las estructuras de migración específicas y de las cuestiones sociales abiertas. Las pervivencia de ciertas imágenes negativas es indicio de que las actitudes xenófobas latentes parecen estar aún más arraigadas en la sensibilidad colectiva que los temores ante una sociedad extremadamente competitiva. Sin embargo aquellas pueden reavivar éstos, sobre todo entre gente desorientada e insegura respecto a su propia identidad. De hecho, la xenofobia de los países de la Unión aparece hoy no como resultado de la mera pervivencia de prejuicios sociales, sino como expresión de un conflicto social. Como observan Lebhart y Münz en Austria, precisamente la posibilidad de una integración satisfactoria de los inmigrantes es lo que parece

49 Lebhart \& Münz (1999), pp. 10-11.

50 Díez Nicolás (1999), p. 27. 
desatar resistencias y miedos entre sectores de la población con más miedo a sufrir la exclusión social ${ }^{51}$. Observaciones realizadas en el marco de los estudios sobre familias inmigrantes citados, por ejemplo el comentario en forma de reproche a los inmigrantes: "Se apoyan unos a otros!", parecen corroborar esta explicación.

En estas sociedades más informadas pero no necesariamente mejor orientadas hay muchas personas que parecen experimentar graves dificultades para volver a orientarse en un entorno social que perciben como revuelto. Esto puede suceder bien debido a debilidad psíquica, o bien porque las cotas de bienestar alcanzadas o que se pretendía alcanzar, se perciben amenazadas. Esta "frustración relativa" 52 que no depende de la situación material de las personas afectadas, sino que está en relación con unas expectativas personales que a su vez están definidas socialmente, se vuelve fácilmente contra grupos más débiles. Los mecanismos de la globalización no son evidentes, en cambio algunas de sus consecuencias, entre ellas la presencia de inmigrantes en la calle, en los hospitales, en las escuelas, en el vecindario, sí lo son. Ellos y sus descendientes son percibidos como "extraños" por mucho que se adapten a las condiciones de vida del país receptor, lo cual, por otro lado, no tiene por qué ocurrir necesariamente.

En el caso de los "nuevos pobres" 53 o de los migrantes, en la medida en que se pierden de vista los factores estructurales que provocan la dinámica de los procesos de exclusión social, se asiste al fenómeno de estigmatización de la pobreza. Esta evolución suele producirse paralela a diferentes reacciones de marginalización por parte de las personas, familias y grupos afectados ${ }^{54} y$, evidentemente, en el caso de los inmigrantes y sus familiares, repercute en la manera de insertarse en el país receptor.

Con todo, los estereotipos y prejuicios no bastan para explicar la exclusión de inmigrantes y de sus descendientes. Las condiciones objetivas y las actitudes y comportamientos colectivos se refuerzan recíprocamente. Si se

51 EUMC (1998). LebHart \& Münz (1999), p. 115.

52 MAYer (1999), p. 82.

53 Quienes en los estudios de pobreza aparecen clasificados dentro de los "grupos de riesgo": Vgl. EUROSTAT (2000), p. 95.

54 Así por ejemplo en muchos estudios sobre familias con miembros que sufren el paro de larga duración, se observa la "huída de la vida social", es decir, la tendencia a evitar contactos con gente de su entorno inmediato. Fernández de LA Hoz \& Pflegerl (1999b), p. 395. 
analizan las condiciones de vida, puede verse claramente que esta población está más afectada que el resto por mecanismos de segregación y discriminación, que se manifiestan en la existencia de un mercado de trabajo y de vivienda duales. En ambos se favorece a los ciudadanos de los países receptores tanto a través de normas jurídicas como de mecanismos informales ${ }^{55}$. De ahí la importancia del marco legal como directamente responsable de la integración o exclusión de inmigrantes.

\subsection{El debate político}

Las personas inmigradas y sus descendientes suelen vivir en condiciones claramente peores que el resto de la población. A todas estas circunstancias hay que añadir los obstáculos que encuentran para acceder a la participación política. Por ello, los inmigrantes, a diferencia de otros grupos amenazados de exclusión o en trance de sufrirla, son los únicos que hoy son objeto de una "exclusion activa" 56 . Huelga decir que todas estas circunstancias no favorecen en absoluto los procesos de integración de inmigrantes y sus descendientes. Otra cosa es su inserción, es decir, su modo de reanudar la vida en el país receptor tras la cesura establecida por el cambio de país. Todo inmigrante se inserta. La pregunta es cómo. Y vale la pena reflexionar sobre las consecuencias de los diferentes tipos de inserción tanto para sus autores como para el país receptor.

En líneas generales, desde comienzos de los 90 los países miembros de la UE están reaccionando a la migración con políticas de cierre de fronteras y control de flujos. Rara vez se da una prioridad decidida a medidas de integración, si bien los acentos entre los diferentes países varían sensiblemente ${ }^{57}$. La responsabilidad de las instituciones políticas se deriva de su papel como instancia controladora de flujos, de la importancia del marco jurídico que han de asumir los inmigrantes y de la influencia de los dirigentes políticos sobre la futura orientación de la opinión pública ${ }^{58}$.

\footnotetext{
55 LebHart \& Münz (1999), p. 8

56 "Indeed in much of Europe, legally settled immigrants do not have the political right to vote because of the difficulties $\&$ delays in acquiring citizenship. This keeps them outside the political process in a systematic way- this is clearly an active exclusion". Sen (2000), p. 16.

$57 \mathrm{Vgl.:}$ Cinar e.a.

58 Thalhammer et Al. (2001), p. 12.
} 
Las cuestiones relativas a los inmigrantes -y también a otros grupos sociales que corren riesgo de sufrir procesos de marginación- suelen articularse en torno al debate sobre su "integración". La cuestión clave es qué se entiende por este término. 0 planteado de otro modo: cuál es el modelo de vida en común que estamos desarrollando en nuestro país y en la Unión Europea. Las respuestas concretas que se van dando a esta cuestión dependen de la tradición política propia, de los temores y las expectativas de las sociedades receptoras y también de la vida y las formas de inserción de los inmigrantes. Como advierte Dominique Schnapper, refugiarse desde el análisis social en la denuncia de los déficits políticos del país propio y de la UE

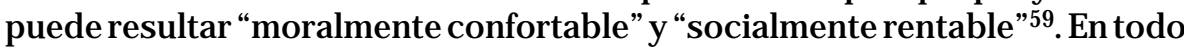
caso es una actitud susceptible de caer en la ligereza cuando no se analizan bien las dificultades reales en el camino de una integración social de los países de la UE, unica vía para poder desarticularlas.

La integración social, tal y como se concibe en las instituciones de la UE es, - como su polo opuesto, la exclusión- un proceso. Proceso de participación social progresiva y de adquisición de derechos civiles, sociales y políticos de todas las mujeres y los hombres que viven en La UE. Hoy los inmigrantes siguen siendo excluídos de los derechos políticos debido a que éstos continúan vinculados a la nacionalidad ${ }^{60}$. Ello les acarrea en la práctica una merma de sus derechos sociales. Ahora bien: "Una sociedad que se refiere a principios universales, traiciona por definición los valores a los que se remite. ¿En qué momento esta traición pone en cuestión el fundamento de la organización social?" ${ }^{61}$. Desde esta perspectiva y también desde el conocimiento de mujeres y hombres concretos que viven en condiciones que no desearíamos para nosotros, se impone el trabajo por una integración social que incluya a todos. Respecto a la migración, es tiempo de tomar consciencia de sus "para-dojas". Ellas constituyen indicadores particularmente valiosos de los desfases sociales entre lo vivido y lo sancionado.

\footnotetext{
59 SChNAPPER (1998), p. 497.

60 Vitorino, A. (2000), Intégration des ressortissants de pays tiers en situation légale. Commissione Européenne SPEECH/00/353):

61 Ibid.
} 


\section{Bibliografía citada}

Ahlheim, K., \& Heger, B. (2000). "Die fremden Konkurrenten. Ergebnisse einer emirsichen Studie über Fremdenfeindlichkeit". WSI-Mitteilungen, 6, pp. 375-382.

Bourdieu, P. (1999). Preface. In A. Sayad (Ed.), La double absence. Des illusions de l'émigré aux souffrances de l'immigré, pp. 9-13. Paris: Seuil.

ButterwegGe, C. (2000). "Zuwanderung und Wohlfahrtsstaat im Zeichen der Globalisierung - antagonistischer Widerspruch oder nützliche Wechselbeziehung?". In C. ButTerWEGGe \& G. Hentges (Eds.), Zuwanderung im Zeichen der Globalisierung. Migrations- Integrations- und Minderheitenpolitik, $\mathrm{p}$. 274. Opladen: Leske +Budrich.

Camilleri, C. (1996). Psychologie et culture: Concepts et méthodes. Paris: Armand Colin.

CASTLES, S. (2000) . "Migración internacional a comienzos del siglo XXI:Tendencias y problemas mundiales". Revista Internacional de Ciencias Sociales, Septiembre, pp. 17-31.

CinaR, D., Davy, U., \& WaldRauch, H. (1999). "Rechtliche Instrumente der Integration von Einwanderern im europäischen Vergleich". In H. FASSMANN, H. Matuschek \& E. Menasse (Eds.), Abgrenzen, Ausgrenzen, Aufnehmen. Empirische Befunde zu Fremdenfeindlichkit und Integration, pp. 53-75. Wien: Drava.

Dietzel-Papakyriakou, M. (1993a). Altern in der Migration. Die Arbeitsmigranten vor dem Dilemma: zurückkehren oder bleiben. Stuttgart: Enke Verlag.

Dietzel-Papakyriakou, M. (1993b). “Die älteren Ausländer in der Bundesrepublik Deutschland - Soziodemographische Aspekte". In O.J ohannes (Ed), Die älter werdende Gesellschaft, pp. 171-193. Wiesbaden: Bundesinstitut für Bevölkerungsforschung.

Díez Nicolás, J . (1999). Los españoles y la inmigración. Madrid: Ministerio de Trabajo y Asuntos Sociales.

EUMC (1998). Un âme pour l'Europe. RapportAnnuel 1998, 1ère partie. Vienne: Observatoire Européen des Phénomènes Racistes et Xénophobes.

Comunidad Europea (2001a). Comunicación de la Comisión al Consejo, al Parlamento Europeo, al Comité Económico y Social y al Comité de las Regiones. Objetivos estratégicos 2002-2005. Bruselas: Comunidad Europea. 
Comunidad Europea (2001b). Comunicación de la Comisión al Consejo, al Parlamento Europeo, al Comité Económico y Social y al Comité de las Regiones. Proyecto de informe conjunto sobre la integración social. Bruselas: Comunidad Europea.

EUROSTAT (2000). La situation sociale dans I'Union Européenne 2000. Luxembourg: Communautés européennes.

Fernández de la Hoz, P., \& Pflegerl, J. (1999a). “Familienleben als Schlüssel zur Integration". In J. u. F. BUNDESMINISTERIUM FÜR UMWELt (Ed.), Zur Situation von Familie und Familienpolitik in Österreich .4. Österreichischer Familienbericht - Familie zwischen Anspruch und Alltag, pp. 364-382. Wien: Bundesministerium für Umwelt, Jugend und Familie.

Fernández de la Hoz, P., \& Pflegerl, J . (1999b). “Familienleben und Arbeitslosigkeit". In J. U. F. BUndeSMINISTERIUM FÜR UMWELt (Ed.), 4. Österreichischer Familienbericht: Familie zwischen Anspruch und Alltag. Zur Situation von Familie und Familienpolitik in Österreich, pp. 382-399. Wien: Bundesministerium für Umwelt, J ugend und Familie.

Fernández de la Hoz, P., \& Pflegerl, J . (1999). Migrantlnnen im Spital. Workshop für Mitarbeiterlnnnen in Gesundhaitseinrichtungen der Stadt Wien, Kompendium der Familienforschung in Österreich 1999. Wien: Österreichisches Institut für Familienforschung (ÖIF).

GäCHTER, August (1998). Die Integration der niedergelassenen ausländischen Wohnbevölkerung in den Arbeitsmarkt. Wien, Institut für Höhere Studien

Heckmann, F. (1992). Ethnische Minderheiten, Volk und Nation. Stuttgart: Ferdinand Enke Verlag.

KASER, K. (1995). Familie und Verwandtschaft auf dem Balkan. Analyse einer untergehenden Kultur. Wien: Böhlau.

Khosrokhavar, F. (1997). L'islam des jeunes. Paris: Flammarion.

LichtenBeRger, E. \& FASSMANn, H. (1984). Gastarbeiter: Leben in zwei Gesellschaften. Wien: H. Böhlau.

LebHaRT, G., \& Münz, R. (1999). Migration und Fremdenfeindlichkeit. Fakten, Meinungen und Einstellungen zu internationaler Migration, ausländischer Bevölkerung und staatlicher Ausländerpolitik in Österreich. Wien: Institut für Demographie.

LoyCKE, A. (1992). “Der Gast, der bleibt”. In A. Loycke (Ed.), Der Gast, der bleibt. 
Dimensionen von Georg Simmels Analyse des Fremdseins, pp. 103-123. Frankfurt: Campus.

MAYER, N. (1999). Ces français qui votent FN. Paris: Flammarion.

MejeR, L. (2000). “L'exclusion sociale dans les États membres de I'UE - Les ménages mono parentaux et les chômeurs sont particulièrement exposés". http://europa.eu.int/comm/eurostat/datashop/print-product/ FR?catalogue $=$ Eurostat $\&$ product $=3-31012000-F R-B P-F R \&$ type $=0$ df $: 30$. April 2001

Mitterauer, M. (1990). Historisch-anthropologische Familienforschung: Fragestellungen und Zugangsweisen. Wien: Böhlau.

ParnReiter, C. (2000). "Theorien und Forschungsansätze zu Migration". In K. HUSA E.A. (Ed.), Internationale Migration, pp. 25-52. Frankfurt: Brandes \& Apsel.

ParnReiter, C. (2001). "Migrationstheorien und Migrationspolitik". Kontraste, 7, pp. 2-5.

PerRone, L. (1995). Porte chiuse. Cultura e tradizioni africane attraverso le storie di vita degli immigranti. Napoli: Liguore.

Pflegerl, J., \& Fernández de la Hoz, P. (2001). Die Bedeutung des Wohnens für Migrantenfamilien in Österreich. Wien: Österreichisches Institut für Familienforschung.

Pumares, P. (1996). La integración de los inmigrantes marroquíes. Familias marroquíes en la Comunidad de Madrid, Fundación "La Caixa".

Recolons, L. (2001). “Migration in the world: Links with human richness and material poverty". In S. D'SouzA (Ed.), Population and poverty issues at the dawn of the 21st century, pp. 35-63. New Delhi: Indian Social Institute.

SAYAD, A. (1991). L'immigration ou les paradoxes de l'alterité. Paris - Bruxelles: De Boeck \& Larcier.

Schnapper, D. (1998). La rélation à l'autre. Au coeur de la pensée sociologique. Paris: Gallimard.

Sen, Amartya (2000). Social exclusion: concept, application, and scrutiny. Manila: Asian Development Bank.

SöDERING, I. (1997). “Life management and the attitudes towards immigrants in Finland", EAPSInternational Conference, J une 11-13 1997 (s.p.). In Cracow, 
Poland: Mimeographiertes Manuskript.

TAGUiefF, P. A., \& WieWIORKA, M. (1998). "Le racisme - Le multiculturalisme". Cahier du CEVIPOF, 20, s.p.

Thalhammer, E., Zucha, V., Enzenhofer, E., Salfinger, B., \& Ogris, G. (2001). Attitudes towards minority groups in the European Union. A special analysis of the Eurobarometer 2000 opinion poll on behalf of the European Monitoring Centre on Racism and Xenophobia. Technical Report by SORA Vienna: EUMC.

Treibel, A. (1990): Migration in modernen Gesellschaften. Soziale Folgen von Einwanderung und Gastarbeit. Weinheim und München: Juventa.

Tribalat, M., Simon, P., \& Riandey, B. (1996). De l'immigration à l'assimilation: enquête sur les populations d'origine étrangère en France. Paris: Editions La Découverte: INED.

Wroblewsky, A. (1998). "Der Arbeitsmarkt für AusländerInnen". In C.- L. HofiNGER, e.a. (Ed), Einwanderung und Niederlassung II Soziale Kontakte, Diskriminierungserfahrung, Sprachkenntnisse, Bleibeabsichten, Arbeitsmarktintegration und Armutsgefärdung der ausländischen Wohnbevölkerung in Wien. Endbericht Wien:IHS, S. 132-156

ZANFrINI, L. (1998). Leggere le migrazioni. I risultati della ricerca emopirica, le categorie intrepretative, i problemi aperti. Milano: Franco Angeli. 